\title{
PREDIKSI BIDANG PENELITIAN DAN REKOMENDASI DOSEN PEMBIMBING SKRIPSI BERDASARKAN KONTEN LATAR BELAKANG PADA NASKAH PROPOSAL MENGGUNAKAN METODE MULTI-CLASS SUPPORT VECTOR MACHINE DAN WEIGHTED PRODUCT
}

\author{
Yustinus Radityo Pradana*1, Ahmad Afif Supianto², Yusi Tyroni Mursityo ${ }^{3}$ \\ ${ }^{1,3}$ Sistem Informasi, Fakultas Ilmu Komputer, Universitas Brawijaya \\ ${ }^{2}$ Teknik Informatika, Fakultas Ilmu Komputer, Universitas Brawijaya \\ Email: ${ }^{1}$ radityopradana@student.ub.ac.id, ${ }^{2}$ afif.supianto@ub.ac.id, ${ }^{3}$ yusi_tyro@ub.ac.id \\ *Penulis Korespondensi
}

(Naskah masuk: 16 Desember 2020, diterima untuk diterbitkan: 24 Maret 2021)

\begin{abstract}
Abstrak
Pada Fakultas Ilmu Komputer Universitas Brawijaya (FILKOM UB), pengerjaan skripsi dimulai dengan melakukan pembuatan praproposal yang berisi latar belakang dan bidang skripsi. Dalam pengerjaan skripsi, mahasiswa butuh pendampingan oleh dosen pembimbing. Dosen pembimbing berfungsi sebagai motivator, pendamping serta pemberi arahan bagi mahasiswa yang sedang mengerjakan skripsi. Dosen pembimbing menjadi krusial dalam pengerjaan skripsi seorang mahasiswa. Oleh karena hal tersebut, pemilihan dosen pembimbing yang memiliki bidang keahlian yang sesuai dengan topik skripsi sangat penting. Pada FILKOM UB, dosen dengan bidang keahlian yang serupa dikumpulkan dalam sebuah kelompok jabatan fungsional dosen (KJFD). Mahasiswa FILKOM UB dapat berdiskusi dengan ketua program studi atau koordinator KJFD untuk mendapatkan rekomendasi dosen yang memiliki bidang keahlian sesuai topik skripsi. Topik skripsi dapat ditentukan dari latar belakang sebuah proposal skripsi. Penelitian ini bertujuan untuk mengetahui tingkat akurasi prediksi KJFD menggunakan algoritme Multi-class Support Vector Machine dan tingkat akurasi rekomendasi dosen pembimbing menggunakan algoritme Weighted Product. Prediksi KJFD dilakukan berdasarkan latar belakang pada naskah skripsi. Rekomendasi dosen diberikan berdasarkan kesesuaian bidang KJFD dosen dengan topik dan beberapa data dosen yang didapatkan dari unit Pengelola Sistem Informasi, Infrastruktur TI dan Kehumasan Fakultas Ilmu Komputer (PSIK FILKOM) seperti jurusan dosen, sisa kuota bimbingan, tingkatan gelar, dan beban kerja. Hasil pengujian menghasilkan akurasi prediksi bidang skripsi memiliki nilai precision tertinggi sebesar 0,93 dan akurasi rekomendasi dosen pembimbing memiliki nilai precision@k tertinggi sebesar 0,1678 saat nilai $\mathrm{k}$ berjumlah 4 . Hasil pengujian akurasi tersebut menampilkan bahwa prediksi bidang skripsi dapat dilakukan dengan sangat baik menggunakan Multi-class Support Vector Machine. Sementara rekomendasi dosen pembimbing dapat dilakukan secara optimal dengan jumlah dosen yang direkomendasikan sebanyak 4 dosen.
\end{abstract}

Kata kunci: rekomendasi dosen, pembimbing, support vector machine, weighted product, topik, skripsi

\section{RESEARCH FIELD PREDICTION AND THESIS SUPERVISOR RECCOMENDATION BASED ON INTRODUCTION CONTENTS IN THE PROPOSAL MANUSCRIPT USING MULTI-CLASS SUPPORT VECTOR MACHINE AND WEIGHTED PRODUCT}

\begin{abstract}
In Fakultas Ilmu Komputer Universitas Brawijaya (FILKOM UB), thesis work started by making preproposal which contains the background and thesis field/topic. In the working of thesis, undergraduate student needs to be accompanied by a supervisor. Supervisor serve as motivator, companion, and guider for undergraduate students who are doing their thesis research. Supervisor roles become crucial in the working of thesis. Therefore, the selection of supervisor who have areas of expertise that matching with thesis topic is very important. In FILKOM UB, supervisor with similar expertise gathered in a lecturer functional group (KJFD). Students of FILKOM UB may discuss with the head of programme or KJFD coordinator to get a supervisor reccomendation who suitable with the topic of thesis. The topic of thesis can be determined by the introduction contents in proposal manuscript. This research aims to discover the accuracy of KJFD prediction using Multiclass Support Vector Machine and the accuracy of supervisor reccomendation using Weighted Product. KJFD prediction formulated based on introduction contents in proposal manuscript. Supervisor recommendation done
\end{abstract}


based on the coherency of supervisor's expertise with the thesis's topic and also based on some supervisor data that was obtained from unit Pengelola Sistem Informasi, Infrastruktur TI dan Kehumasan Fakultas Ilmu Komputer (PSIK FILKOM). The data that was obtained from unit PSIK FILKOM are supervisor's majors, remaining quota for supervising, degree level, and work load. Testing result shows the accuracy of thesis's topic having precision value of 0,93 and accuracy of the supervisor predicition having precision@k value of 0,1678 with $k$ value of 4 . The accuracy test result shows that thesis topics prediction can be done very well using Multiclass Support Vector Machine. While supervisor reccomendation can be done optimally when the number of recommended supervisor is 4.

Keywords: supervisor reccomendation, guider, support vector machine, weighted product, topic, thesis

\section{PENDAHULUAN}

Dalam proses pengerjaan skripsi, dosen pembimbing berfungsi sebagai motivator, pendamping, kolaborator, serta pemberi arahan bagi mahasiswa yang sedang mengerjakan skripsi. Oleh karena hal tersebut, peran dosen pembimbing dalam proses pengerjaan skripsi menjadi krusial. Berdasarkan hasil penelitian yang dilakukan oleh Lestari (2012), bahwa ada hubungan positif yang signifikan antara harapan mahasiswa terhadap dosen pembimbing dengan motivasi dalam menyelesaikan skripsi. Oleh karena hal tersebut, maka hubungan antara dosen pembimbing dengan mahasiswa bimbingan menjadi sangat penting.

Pada Fakultas Ilmu Komputer Universitas Brawijaya (Filkom UB), mahasiswa dapat memilih calon dosen pembimbing dengan cara pendekatan personal atau dengan melalui rekomendasi. Pendekatan personal yang dimaksud adalah: (1) mahasiswa dapat memilih dosen yang menyediakan proyek dosen, (2) mahasiswa dapat memilih dosen yang menjadi pengajar pada mata kuliah yang pernah diikuti, (3) mahasiswa dapat memilih dosen berdasarkan pengalaman seminar atau magang. Pada Filkom UB, bidang keahlian dosen dikumpulkan pada satu Kelompok Jabatan Fungsional Dosen(KJFD). Sesuai alur skripsi pada panduan pengerjaan skripsi mahasiswa Filkom UB (2018), rekomendasi dapat diperoleh mahasiswa melalui ketua program studi atau koordinator kelompok jabatan fungsional dosen berdasarkan topik yang ingin diangkat. Namun, dikarenakan terbatasnya jumlah koordinator KJFD dan ketua program studi, tidak semua mahasiswa dapat memohon rekomendasi kepada mereka. Oleh karena hal tersebut, maka pemilihan dosen pembimbing didominasi dengan pendekatan personal. Pengambilan keputusan pemilihan dosen pembimbing berdasarkan pendekatan personal umumnya didominasi oleh intuisi mahasiswa. Hal ini menimbulkan risiko terjadinya pemilihan calon dosen pembimbing yang tidak sesuai dengan materi/topik skripsi. Ketidaksesuaian tersebut mengakibatkan pengerjaan skripsi yang kurang efektif dan membuka kemungkinan untuk pemilihan calon dosen baru yang lebih menguasai topik/materi.

Penelitian mengenai rekomendasi kolaborator telah dilakukan oleh beberapa penelitian terdahulu, termasuk penggabungan informasi jaringan kolaborator dan publikasi peneliti (Kong et al., 2016), penggunaan metode nearest neighbor berdasarkan algoritme random walk (Yang et al., 2018), dan rekomendasi berdasarkan hubungan kedekatan kelompok konferensi (Wang et al., 2019). Penelitian yang dilakukan oleh Zhang et al. (2016) berusaha untuk menjawab permasalahan pemilihan supervisor atau pembimbing dengan mempertimbangkan relevansi antar penelitian, konektivitas dengan hubungan sosial, dan kualitas penelitian. Penelitian sejenis juga dilakukan oleh Hasan dan Schartz (2019) menggunakan sistem keputusan multi kriteria dengan menggabungkan fuzzy analytic hierarchy process dengan algoritme information retrieval-based similarity.

Penelitian terdahulu mengenai penggunaan Support Vector Machine telah dibahas oleh Sulaeman, et al. (2019). Penelitian ini membahas mengenai penggunaan TF-IDF dan Support Vector Machine untuk melakukan text mining dalam bentuk klasifikasi sentimen opini. Penelitian ini menghasilkan bahwa penggunaan support vector machine dengan TF-IDF dapat digunakan untuk memproses teks dalam teks mining. Untuk perekomendasian dosen menggunakan data spesifik program studi Sistem Informasi Fakultas Ilmu Komputer Universitas Brawijaya telah dilakukan oleh Putri, et al. (2019). Penelitian ini mencoba membangun sistem pendukung keputusan untuk perekomendasian dosen pembimbing berdasarkan data penelitian dosen, KJFD, jurusan, kuota bimbingan, jabatan, dan beban kerja dosen menggunakan algoritme Winnowing-Weighted Product. Penelitian ini menghasilkan bahwa algoritme Winnowing-Weighted Product dapat digunakan untuk perekomendasian dosen.

Berdasarkan penelitian yang dilakukan sebelumnya terdapat sebuah gap diantaranya pada penelitian sebelumnya terdapat penelitian yang membahas mengenai bidang dosen spesifik KJFD, namun pada penelitian tersebut data KJFD adalah data input dari manusia tanpa proses klasifikasi menggunakan sistem. Kedua, penelitian sebelumnya tidak mempergunakan naskah latar belakang penelitian sebagai salah satu data untuk dipertimbangkan. Celah-celah peneltian tersebut yang akan berusaha dijawab pada penelitian ini. 
Penelitian ini mencoba untuk menggunakan naskah latar belakang sebagai dasar pertimbangan dalam menentukan bidang dan memberikan rekomendasi dosen pembimbing. Metode Multiclass Support Vector Machine digunakan untuk menentukan dan memprediksi bidang penelitian. Sementara metode Weighted Product digunakan sebagai pendukung keputusan untuk memberikan rekomendasi pembimbing yang sesuai untuk mahasiswa tersebut. Oleh karena itu, penelitian ini mengusung pertanyaan penelitian tentang berapa tingkat akurasi prediksi pada kesesuaian KJFD dengan metode Multi-class Support Vector Machine dan akurasi pada rekomendasi dosen pembimbing dengan metode Weighted Product.

\section{METODE PENELITIAN}

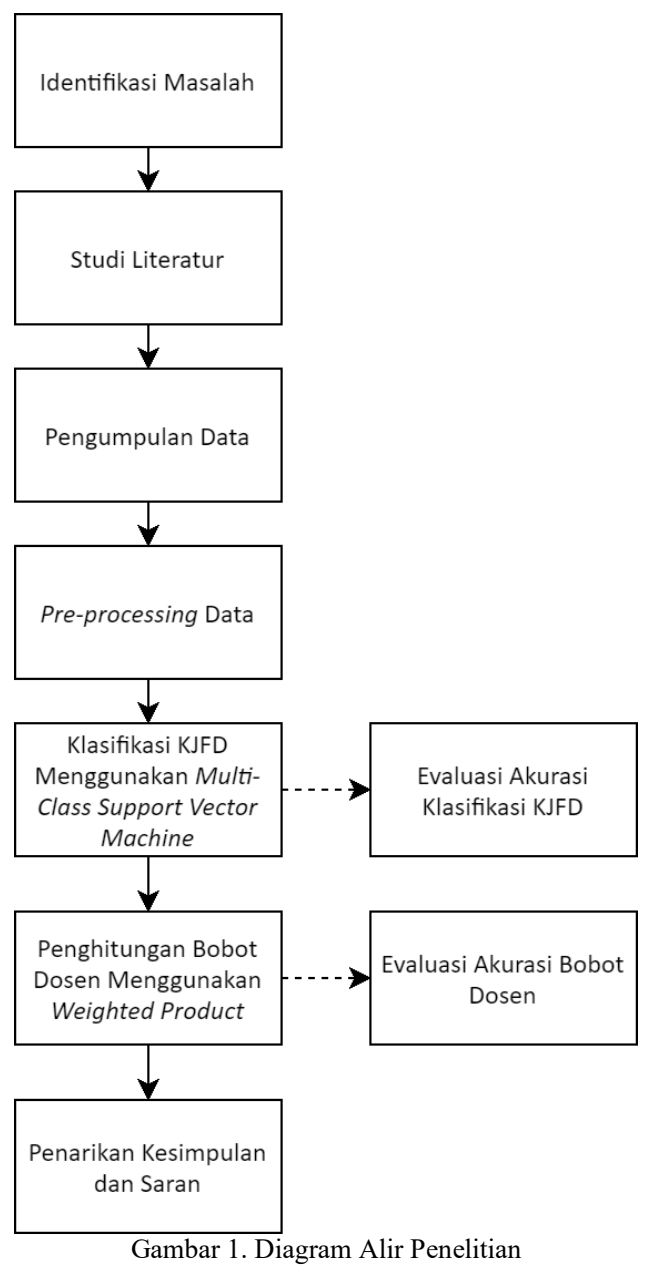

Gambar 1 menampilkan alur penelitian. Tahap pertama dilakukan pengamatan kondisi lapangan mengenai pemilihan dosen pembimbing. Selanjutnya dilakukan studi pustaka dengan mengumpulkan informasi mengenai teori yang dibutuhkan. Pengumpulan data dilakukan dengan mengumpulkan latar belakang jurnal yang didapatkan dari Jurnal Pengembangan Teknologi Informasi dan Ilmu Komputer. Data berasal dari mahasiswa yang yudisium pada tahun 2018 hingga Agustus 2019.
Tahap selanjutnya adalah preprocessing data, Klasifikasi KJFD menggunakan Multi-class Support Vector Machine, Perhitungan bobot pembimbing menggunakan Weighted Product. Kemudian dilakukan pengujian sistem untuk mengetahui akurasi dari klasifikasi bidang dan rekomendasi pembimbing. Penelitian ini diakhiri dengan penarikan kesimpulan dan saran.

\subsection{Preprocessing Data}

Tahapan-tahapan yang dilakukan untuk preprocessing data, yaitu:

1. Case Folding

Case Folding adalah sebuah teknik untuk mengubah semua huruf menjadi huruf kecil agar perbandingan case-insensitive dapat dilakukan.

2. Penghapusan Tanda Baca

Tanda baca atau karakter spesial tidak memiliki signfiikansi saat content-based matching dan harus dihilangkan sebelum mengaplikasikan algoritme klasifikasi.

3. Stemming

Stemming adalah metode yang digunakan untuk mengidentifikasi kata dasar dari sebuah kata.

4. Penghapusan Stopword

Stopword merupakan kata yang umum digunakan sehingga muncul dalam jumlah besar namun tidak memiliki makna secara signifikan. Kemunculan kata-kata tersebut menghasilkan noise yang mengakibatkan algoritme klasifikasi menganggap kata tersebut menjadi kata yang sering muncul dan penting.

5. Tokenisasi

Tokenisasi adalah pemisahan kata pada dokumen menjadi token. Dalam implementasinya setiap token akan dikumpulkan dalam bentuk array.

6. Pembobotan kata

Pembobotan kata dilakukan dengan memanfaatkan metode pembobotan Term Frequency - Inverse Document Frequency (TF-IDF). Pembobotan TF-IDF mengubah kata menjadi angka bobot berdasarkan jumlah kemunculan kata dan keunikan kata pada dokumen.

\subsection{Klasifikasi Bidang Skripsi}

Kelas bidang KJFD disesuaikan dengan KJFD yang terdapat pada Program Studi Sistem Informasi Universitas Brawijaya, diantaranya: Pengembangan Sistem Informasi (PSI), Tata Kelola dan Manajemen SI (TKMSI), Manajemen Data dan Informasi (MDI), Integrasi Teknologi Informasi (ITI), Sistem Informasi Geografis (SIG). Pengelompokan terhadap kelas dilakukan dengan menggunakan pendekatan supervised learning. Pendekatan supervised learning dilakukan dengan mengimplementasikan algoritme 
Multi-class Support Vector Machine pada bahasa pemrograman Python meggunakan library machine learning bernama scikit-learn. Support Vector Machine (SVM) yang digunakan adalah SVM dengan kernel radial basis function (rbf), C sebesar 1000, dan gamma sebesar 0,001.

\subsection{Penentuan Nilai BM25}

Nilai BM25 untuk setiap alternatif pembimbing ditentukan oleh web service yang diimplementasikan menggunakan bahasa Python dengan menggunakan library rank_bm25. Hasil nilai BM25 yang dimiliki setiap skripsi yang telah didapatkan kemudian dikelompokkan menurut pembimbing. Nilai tertinggi pada setiap pembimbing akan merepresentasikan nilai BM25 dari pembimbing tersebut.

\subsection{Perhitungan Weighted Product}

Penelitian ini menggunakan metode Weighted Product untuk melakukan rekomendasi pembimbing skripsi. Weighted Product mempertimbangkan atribut atau kriteria yang diberi beban secara subjektif sesuai dengan tingkat kepentingan dari sebuah atribut atau kriteria. Kriteria dan beban kriteria dijelaskan pada tabel 1. Beban didapatkan berdasarkan diskusi dengan koordinator KJFD dan telah diuji menggunakan pairwise comparison untuk memastikan bahwa beban yang diberikan memiliki konsistensi antara satu dengan yang lain.

Tabel 1. Kriteria dan Beban Kriteria Weighted Product

\begin{tabular}{ccc}
\hline Kode & $\begin{array}{c}\text { Nama } \\
\text { Kriteria }\end{array}$ & Beban \\
\hline C1 & $\begin{array}{c}\text { Kesesuaian } \\
\text { KJFD } \\
\text { Nilai } \\
\text { C2 }\end{array}$ & 0,45 \\
BM25 & 0,27 \\
C3 & $\begin{array}{c}\text { Jurusan } \\
\text { Dosen } \\
\text { C4 }\end{array}$ & $\begin{array}{c}\text { Sisa Kuota } \\
\text { Bimbingan } \\
\text { Tingkatan } \\
\text { Gelar }\end{array}$ \\
C5 & $\begin{array}{c}\text { Beban } \\
\text { Kerja }\end{array}$ & 0,11 \\
C6 & 0,05 \\
\hline
\end{tabular}

\section{HASIL DAN PEMBAHASAN}

\subsection{Preprocessing Data}

Naskah latar belakang penelitian yang akan diproses menggunakan preprocessing data menjadi berikut:

1. Case Folding

Case folding memudahkan sistem untuk dapat mengidentifikasi kata yang sama menjadi satu entitas. Dengan case folding kata "Makan" dan "makan" menjadi satu entitas yang sama. Namun, case folding memiliki kelemahan pada penamaan, sebagai contoh "Gudang Garam" memiliki arti yang berbeda dengan "gudang garam".
2. Penghapusan Tanda Baca

Dengan terhapusnya tanda baca, setiap kata yang sama namun memiliki tanda baca yang berbeda bersatu menjadi satu entitas. Walaupun memiliki konteks yang sama, sistem membaca "makanlah!" dengan "makanlah" sebagai entitas yang berbeda, sehingga diperlukan penghapusan tanda baca.

3. Stemming

Kata 'memakan' dan 'dimakan' memiliki maksud berbeda walaupun keduanya memiliki makna yang sama. Dengan melakukan stemming kata 'memakan' dan 'dimakan' diubah menjadi 'makan', sehingga dua kata tersebut menjadi satu entitas yang sama. Proses stemming dilakukan dengan mengaplikasikan algoritme Nazief dan Adriani pada library Sastrawi.

4. Penghapusan Stopword

Kata stopword pada bahasa indonesia dapat diartikan sebagai kata sambung. Kata sambung pada sebuah naskah dokumen berjumlah cukup banyak. Sebagai contoh, kalimat "Support Vector Machine dan Weighted Product" tidak kehilangan makna jikalau kata "dan" dihapuskan menjadi "Support Vector Machine Weighted Product". Kata stopword dihapus berdasarkan kamus stopword pada library Sastrawi.

5. Tokenisasi

Sebelum diberi pembobotan, setiap kata perlu dipisahkan terlebih dahulu. Oleh karena hal tersebut, diperlukan tokenisasi kata. Tokenisasi kata memisahkan kalimat yang telah dilakukan stemming menjadi array kata. Sebagai contoh kalimat "guna support vector machine" menjadi ['guna','support','vector','machine'].

6. Pembobotan kata

Pembobotan kata mengubah kata tekstual menjadi bentuk matematis yang dapat diperhitungkan oleh sistem. Term Frequency berusaha menghitung perbandingan kemunculan kata dengan jumlah kata dalam dokumen. Inverse Document Frequency berusaha menghitung inverse dari jumlah dokumen yang memunculkan kata tersebut diperbandingkan dengan jumlah dokumen.

Kemudian, kalimat tersebut dipecah menurut entitas kata yang kemudian dilakukan perhitungan Term Frequency dan Inverse Document Frequency. Hasil perhitungan Term Frequency dan Inverse Document Frequency diperkalikan sehingga menghasilkan perhitungan TF*IDF. Perhitungan TF*IDF menjadi bobot setiap kata pada setiap dokumen. 


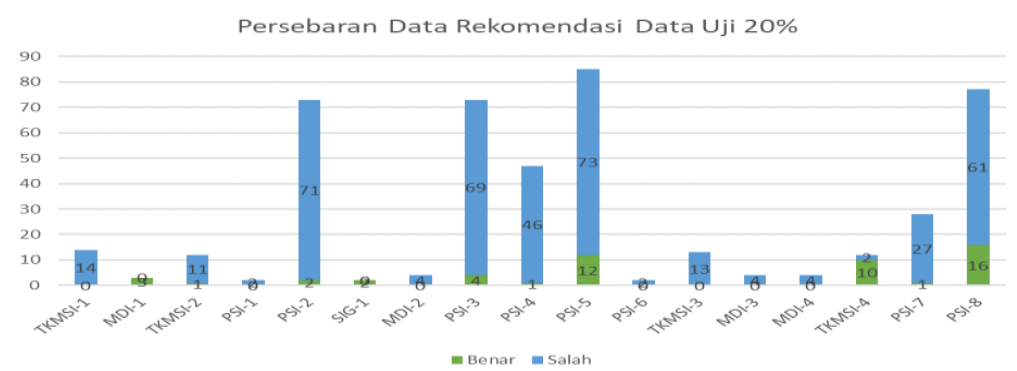

Gambar 2. Grafik Persebaran Data Rekomendasi

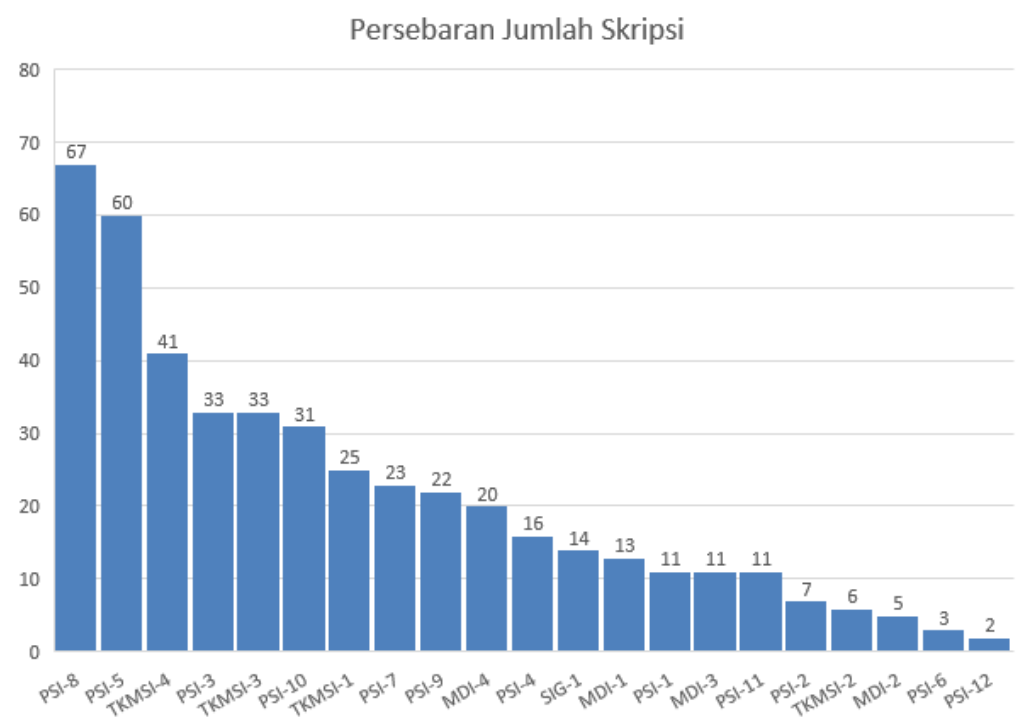

Gambar 3. Grafik Persebaran Jumlah Skripsi

\subsection{Pengujian}

Pengujian memperbandingkan antara jumlah dosen dan jumlah data latar belakang skripsi, terdapat 4 kelompok jumlah dosen yang diuji dengan keterangan sebagai berikut:

1. 26 Dosen. Jumlah 26 dosen adalah seluruh dosen yang membimbing skripsi mahasiswa pada periode yudisium Januari 2018 hingga Agustus 2019;

2. 24 Dosen. Jumlah 24 dosen adalah dosen yang membimbing skripsi mahasiswa pada periode yudisium Januari 2018 hingga Agustus 2019 dan jumlah bimbingan skripsinya lebih dari satu;

3. 23 Dosen. Jumlah 23 dosen adalah dosen yang membimbing skripsi mahasiswa pada periode yudisium Januari 2018 hingga Agustus 2019 yang aktif dalam pembimbingan skripsi tahun ajaran 2019/2020;

4. 21 Dosen. Jumlah 21 dosen adalah dosen yang membimbing skripsi mahasiswa pada periode yudisium Januari 2018 hingga Agustus 2019 yang aktif dalam pembimbingan skripsi tahun ajaran 2019/2020 dan jumlah bimbingan skripsinya lebih dari satu;

Pengujian precision dilakukan dengan membagi data training $70 \%$ dari total data dan data uji $30 \%$ dari total data. Pengujian precision memperbandingkan nilai true positive dengan true positive + false positive. Hasil precision klasifikasi KJFD data uji 30\% dijabarkan pada tabel 2 . Pengujian rekomendasi dosen dilakukan dengan menggunakan teori precision@k. Variabel k pada precision@k adalah jumlah dosen yang direkomendasikan pada setiap proses rekomendasi. Nilai k pada penelitian ini adalah 3, 4, dan 5. Grafik hasil pengujian rekomendasi dosen dapat dilihat pada gambar 4 .

Tabel 2. Hasil Precision Klasifikasi KJFD

\begin{tabular}{cc}
\hline Jumlah Dosen & Precision SVM \\
\hline 26 Dosen & 0,93 \\
24 Dosen & 0,923 \\
23 Dosen & 0,9197 \\
21 Dosen & 0,9197 \\
\hline
\end{tabular}

\section{ANALISIS KLASIFIKASI DAN REKOMENDASI}

Berdasarkan hasil precision pada tabel 2 dan grafik precision@k rekomendasi dosen pada gambar 4, ditampilkan bahwa precision rekomendasi (WP) meningkat seiring menurunnya jumlah dosen. Grafik ini menampilkan bahwa semakin rendah variasi dosen, maka semakin tinggi akurasi rekomendasi yang diberikan. Namun, precision klasifikasi bidang (SVM) menurun seiring menurunnya jumlah dosen. Akurasi SVM juga menampilkan akurasi yang tinggi dengan precision tertinggi sebesar 0,93 . 


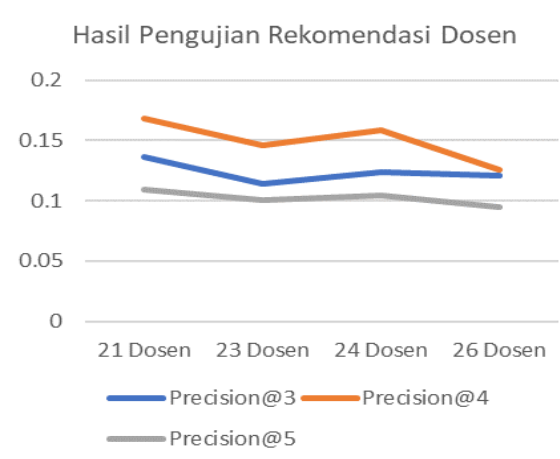

Gambar 4. Grafik Precsion@k Rekomendasi Dosen

Pembagian Jumlah Skripsi Per KJFD

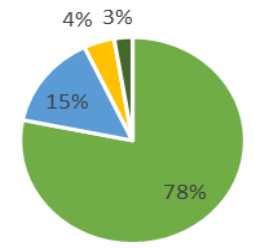

- Pengembangan Sistem Informasi

- Tata Kelola dan Manajemen SI

- Manajemen Data dan Informasi

- Sistem Informasi Geografis

Gambar 5. Grafik Persebaran Data Jumlah Skripsi per KJFD

Pada grafik precision@k rekomendasi dosen, diperlihatkan bahwa precision@k dengan nilai precision terbaik saat $\mathrm{k}$ bernilai 4. Sehingga jumlah dosen optimal yang direkomendasikan pada setiap rekomendasi adalah 4. Nilai precision@k rekomendasi dosen tertinggi adalah 0,1678. Nilai tersebut cukup rendah diperbandingkan nilai precision klasifikasi KJFD. Nilai yang rendah ini dipengaruhi dengan jumlah dosen yang dipertimbangkan dalam pemberian rekomendasi. Klasifikasi KJFD mempertimbangkan 4 KJFD sementara rekomendasi mempertimbangkan dosen yang berjumlah lebih dari 20 .

Grafik persebaran data rekomendasi pada gambar 2 menampilkan persebaran rekomendasi dosen mengalami penumpukan pada 6 dosen. Dosen tersebut adalah PSI-2, PSI-3, PSI-4, PSI-5, PSI-7, PSI-8. Namun, grafik persebaran jumlah skripsi pada gambar 3 menampilkan bahwa penumpukan data rekomendasi tidak dipengaruhi oleh jumlah skripsi yang dibimbing oleh dosen. Hal tersebut ditunjukkan bahwa dosen PSI-2 yang tampil pada hasil rekomendasi sebanyak 73 kali hanya membimbing 7 penelitian skripsi.

Grafik persebaran data jumlah skrpsi per KJFD pada gambar 5 menampilkan bahwa data skripsi didominasi oleh KJFD Pengembangan Sistem Informasi. Hal ini selaras dengan grafik persebaran data rekomendasi yang didominasi oleh dosen pembimbing yang membimbing skripsi dengan KJFD pengembangan sistem informasi. Oleh karena hal tersebut, maka dapat dianalisis bahwa penumpukan data rekomendasi diakibatkan oleh KJFD skripsi yang menumpuk pada KJFD Pengembangan Sistem Informasi. Oleh karena hal tersebut, maka pentingnya perataan pembagian bidang dalam penelitian untuk mengurangi beban jumlah mahasiswa bimbingan pada beberapa dosen dalam bidang tertentu yang di mana secara selaras akan meningkatkan kualitas dari proses pembimbingan penelitian skripsi.

\section{KESIMPULAN DAN SARAN}

Berdasarakan hasil penelitian didapatkan 2 kesimpulan. Akurasi klasifikasi Kelompok Jabatan Fungsional Dosen menggunakan algoritme Multiclass Support Vector Machine adalah sebesar 0,93 pada jumlah data uji sebesar 30\% dari seluruh data. Akurasi klasifikasi Kelompok Jabatan Fungsional Dosen cukup tinggi dan akurat, sehingga dapat disimpulkan bahwa klasifikasi Kelompok Jabatan Fungsional Dosen siap untuk digunakan.

Sementara, akurasi rekomendasi dosen menggunakan algoritme Weighted Product adalah sebesar 0,1678 dengan nilai $\mathrm{k}$ sebesar 4. Dapat disimpulkan bahwa perekomendasian dosen dapat dilakukan secara optimal dengan jumlah dosen yang direkomendasikan sebanyak 4 dosen.

Berdasarakan hasil penelitian terdapat 2 saran yang dapat digunakan untuk penelitian selanjutnya. Perlu dilakukanmya penelitian lebih lanjut mengenai metode dan algoritme lain yang dapat digunakan untuk meningkatkan akurasi rekomendasi dosen pembimbing skripsi menggunakan latar belakang. Kemudian, perlu dilakukannya penelitian lebih lanjut untuk mempercepat proses klasifikasi dan prediksi dosen pembimbing, sehingga pengguna dapat menggunakan sistem yang lebih responsif.

\section{DAFTAR PUSTAKA}

FILKOM UB, 2018. Buku Panduan Skripsi Fakultas Ilmu Komputer. Fakultas Ilmu Komputer Universitas Brawijaya, Malang: Fakultas Ilmu Komputer Universitas Brawijaya.

HASAN, M.A. dan SCHWARTZ, D., 2019. A Multi-criteria Decision Support System for Ph.D. Supervisor Selection: A Hybrid Approach. Proceedings of the 52nd Hawaii International Conference on System Sciences, 6, hal.1823-1832.

KONG, X., JIANG, H., YANG, Z., XU, Z., XIA, F. dan TOLBA, A., 2016. Exploiting publication contents and collaboration networks for collaborator recommendation. PLoS ONE, 11(2), hal.1-13.

LESTARI, N.A., 2012. Hubungan Ekspektansi Terhadap Dosen Pembimbing Dengan Motivasi Menulis Skripsi. Educational Psychology Journal, 1(1), hal.1-8. 
PUTRI, R.A.N., SUPIANTO, A.A. dan PURNOMO, W., 2019. Sistem Pendukung Keputusan untuk Penentuan Dosen Pembimbing Skripsi menggunakan Algoritme Winnowing-Weighted Product. Jurnal Pengembangan Teknologi Informasi dan Ilmu Komputer, 3(9), hal.9132-9138.

SULAEMAN, A.F., SUPIANTO, A.A. dan BACHTIAR, F.A., 2019. Analisis Sentimen Opini Mahasiswa Terhadap Saran Kuesioner Penilaian Kinerja Dosen Dengan Menggunakan Tf-Idf Dan K-Nearest Neighbor. Jurnal Pengembangan Teknologi Informasi dan Ilmu Komputer, 3(6), hal.5647-5655.

WANG, W., LIU, J., YANG, Z., KONG, X. dan XIA, F., 2019. Sustainable Collaborator Recommendation Based on Conference Closure. IEEE Transactions on Computational Social Systems, 6(2), hal.311-322.

YANG, C., LIU, T., LIU, L. dan CHEN, X., 2018. A Nearest Neighbor Based Personal Rank Algorithm for Collaborator Recommendation. In: 2018 15th International Conference on Service Systems and Service Management (ICSSSM). IEEE.hal.1-5.

ZHANG, M., MA, J., LIU, Z., SUN, J. dan SILVA, T., 2016. A research analytics frameworksupported recommendation approach for supervisor selection. British Journal of Educational Technology, 47(2), hal.403420. 
Halaman ini sengaja dikosongkan 